\title{
AVALIAÇÃO DA EFETIVIDADE DE UM PROGRAMA DE ENSINO DA RESSUSCITAÇÃO CARDIOPULMONAR PARA ESTUDANTES DO ENSINO MÉDIO
}

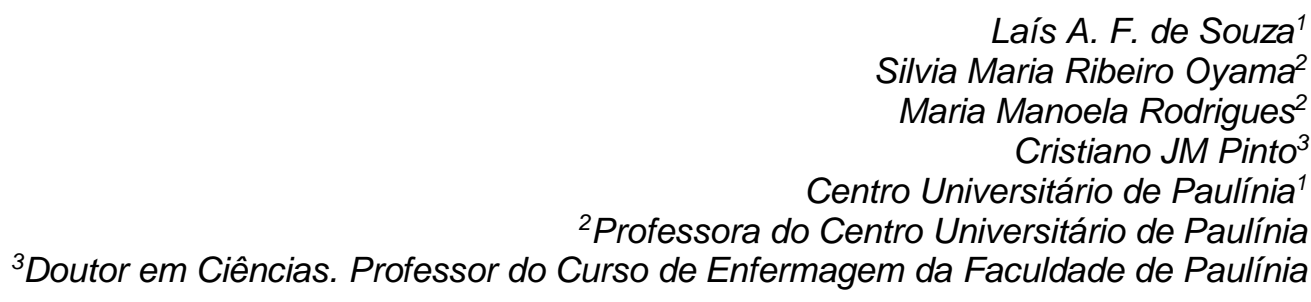

INTRODUÇÃO: Apesar dos avanços nos últimos anos muitas mortes poderiam ser evitadas se pessoas leigas fossem treinadas para a ressuscitação cardiopulmonar $(\mathrm{RCP})$, isso permitiria o atendimento imediato à vítima parada cardiorrespiratória (PCR) fora do ambiente hospitalar, o que é fundamental, pois a cada um minuto que uma vítima de PCR não recebe RCP ela perde de 7 a $10 \%$ de chance de sobrevida. OBJETIVO: Avaliar a retenção do aprendizado sobre RCP seis meses após um treinamento para alunos do ensino médio. MÉTODO: O estudo foi desenvolvido de agosto/2015 a fevereiro/2016 em uma escola privada de Jundiaí-SP, envolvendo alunos do primeiro e segundo ano do ensino médio. A amostra foi composta por 34 alunos com idade entre 13 e 17 anos, uma das pesquisadoras realizou o treinamento seguindo as diretrizes da American Heart Association para o ensino da RCP a leigos. O treinamento foi realizado com grupos de 17 alunos, teve duração aproximada de 1,5 horas, sendo 30 minutos de teoria e uma hora de prática com um manequim para simulação de RCP. A coleta de dados foi realizada em dois momentos, por meio de um questionário para avaliar o conhecimento dos alunos sobre RCP, aplicado antes do treinamento e seis meses após. No dia do treinamento os alunos foram avisados que seriam avaliados seis meses após, sem agendamento prévio. O projeto foi aprovado pelo Comitê de Ética em Pesquisa do Centro Universitário Padre Anchieta (parecer 1.073.569). RESULTADOS: Foi avaliada a resposta correta dos sujeitos a algumas perguntas sobre RCP, a questão inicial era: "qual sua primeira atitude ao encontrar alguém deitado e inconsciente no chão?", antes do treinamento $18 \%$ acertaram e seis meses depois $96 \%(p<0,01)$, na questão "qual o segundo passo ao encontrar alguém inconsciente" acertaram antes $18 \%$ e depois $52 \%(p<0,01)$, sobre "qual a quantidade de compressões torácicas/minuto" o total de acertos foi antes $21 \%$ e depois $61 \%(p<0,01)$, e sobre "qual a profundidade das compressões" acertaram 
antes $41 \%$ e seis meses após $87 \%$ ( $p<0,01)$. CONCLUSÃO: Foi significativa a retenção do aprendizado sobre RCP 6 meses após o treinamento, o grupo estudado preservou o conhecimento de importantes ações para a sobrevivência da vítima de PCR. Estudos com amostras maiores e outros grupos de pessoas e comunidades são necessários para avaliar a eficácia do método em diferentes cenários.

Palavras-chave: Reanimação cardiopulmonar. Parada cardíaca. Ensino fundamental e médio. Serviços de saúde escolar. 